\title{
Non-hodgkin Lymphoma Developing After Discontinuation of Direct-acting Antiviral Treatment for Hepatitis C: A Case Report
}

\author{
Hepatit C'nin Direk Etkili Antivirallerle Tedavisinden Sonra Gelișen Non-hodking \\ Lenfoma: Bir Olgu Sunumu
}

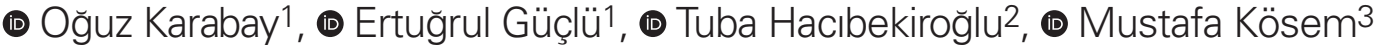 \\ 'Sakarya University Faculty of Medicine, Department of Infectious Diseases, Sakarya, Turkey \\ 2Sakarya University Faculty of Medicine, Department of Haematology, Sakarya, Turkey \\ 3Sakarya University Faculty of Medicine, Department of Pathology, Sakarya, Turkey
}

\begin{abstract}
Today, direct-acting antivirals (DAA) are the main treatment options for hepatitis C infection. However, whether malignancy risk is increased after DAA treatment is a matter of debate. Conflicting results have been reported in the relevant studies. In this paper, we present the case of B-cell non-Hodgkin lymphoma developing after DAA treatment in a patient with complete response to hepatitis $C$ treatment.

Keywords: Hepatocellular carcinoma, hepatitis C, non-Hodgking B cell lymphoma
\end{abstract}

$\ddot{0 Z}$

Günümüzde doğrudan etkili antiviraller (DAA), hepatit $C$ enfeksiyonu için ana tedavi seçenekleridir. Fakat DAA tedavilerinden sonra, hastalarda malignite riskinin arttığına yönelik olgu sunumları vardır. Konuyla ilgili araştırmalarda çelişkili sonuçlar bildirilmiştir. Bu sunumda DAA tedavisi sonrasında tam cevap elde edilen bir hastada tedaviden sonra gelişen $B$ hücreli non-Hodgkin lenfoma ve arasındaki deneyimin paylaşıması amaçlanmıştır.

Anahtar Kelimeler: Karaciğer kanseri, hepatitis C, non-Hodking B cell lenfoma

Karabay 0, Güçlü E, Hacıbekiroğlu T, Kösem M. Non-Hodgkin Lymphoma Developing After Discontinuation of Direct-acting Antiviral Treatment for Hepatitis C: A Case Report. 2019;25:32-34.

\section{Introduction}

The frequency of side effects associated with direct-acting antiviral (DAA) treatment is very low compared to interferon-based treatments (1). Currently, sustained virological response (SVR) has increased significantly with the use of DAA in hepatitis $C$ treatment. More than $95 \%$ of patients have a SVR after DAA-based treatment (2). Moreover, even patients with decompensated cirrhosis may become treatable after treatment with DAAs.

The targeting of new antiviral drugs directly to hepatitis $C$ virus $(\mathrm{HCV})$ replication allowed very high response rates compared to old regimens, regardless of the stage of liver fibrosis. Currently, more than 95\% of patients have a SVR after DAA-based treatment (2). However, there have been a few reports of occurrence of malignancy in patients previously treated with DAAs $(3,4)$. In a multi-center study from Spain with 58 patients and in a single center study with 59 patient from Italy revealed that the incidence of hepatocellular cancer $(\mathrm{HCC})$ was higher in patients treated with DAA $(3,4)$. DAA treatment may also be associated with higher tumor recurrence rate. However, the validity of these data has not been confirmed in different studies (5). In this report, we aimed to present the case of B-cell non-Hodgkin lymphoma (BNHL) in a patient treated with DAA. 


\section{Case}

A 77-year-old woman has been followed up with chronic hepatitis C since 2009. She was previously treated with pegylatedinterferon and ribavirin combination. Although the response was obtained by treatment, relapse was subsequently occurred. In March 2016, laboratory examinations showed a sedimentation rate of $44 \mathrm{~mm} / \mathrm{h}$, an alpha fetoprotein level of $9.29 \mathrm{ng} / \mathrm{mL}$, alanine aminotransferase of $62 \mathrm{IU} / \mathrm{L}, \mathrm{HCV}-\mathrm{RNA}$ viral load of $1471602 \mathrm{IU} /$ $\mathrm{mL}$ with genotype- $1 \mathrm{~b}$ and the patient was anti-HCV-positive. After relapse, we decided to treat the patient with DAA. The initial complete blood test (November 2016) revealed a hemoglobin level of $135 \mathrm{~g} / \mathrm{L}$ (normal range: 115-150 g/L), a white blood

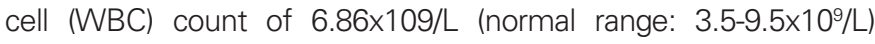
(neutrophil-69.4\%, lymphocyte-23.9\%, monocytes-5.82\%), and a platelet count of 157x109/L (normal range: 125-350x109/L). After splenectomy (December 2017), the values were as follows: WBC: 7060 K/UL (neutrophil-60.8\%, lymphocyte-28\%, monocytes-9.58\%), hemoglobin $11.6 \mathrm{~g} / \mathrm{L}$, and platelet $504 \mathrm{~K} / \mathrm{UL}$. Before treatment, there was no mass detected by abdominal ultrasonography (USG) (It was done at two times at 2016). She was treated with ombitasvir-paritaprevir-ritonavir and dasabuvir (OPRD) for 12 weeks in November 2016. HCV-RNA became negative after the first month of OPRD treatment. SVR was obtained 12 weeks after the treatment.

In June 2017, the patient suffered from fatigue and feeling of fullness and pain in the upper left quadrant. A splenic mass $(9 \times 7$ $\mathrm{cm}$ ) was detected USG in the spleen six months after cessation of the treatment (Figure 1).

In June 2018, surgical resection of the splenic mass was done. Histological analysis of the surgical specimen revealed highgrade B-cell NHL. The patient, who is still being followed up in our clinic was cured after three cycles of chemotherapy (R-CHOP chemotherapy protocol) followed by radiotherapy. Written informed consent was obtained from the patient.

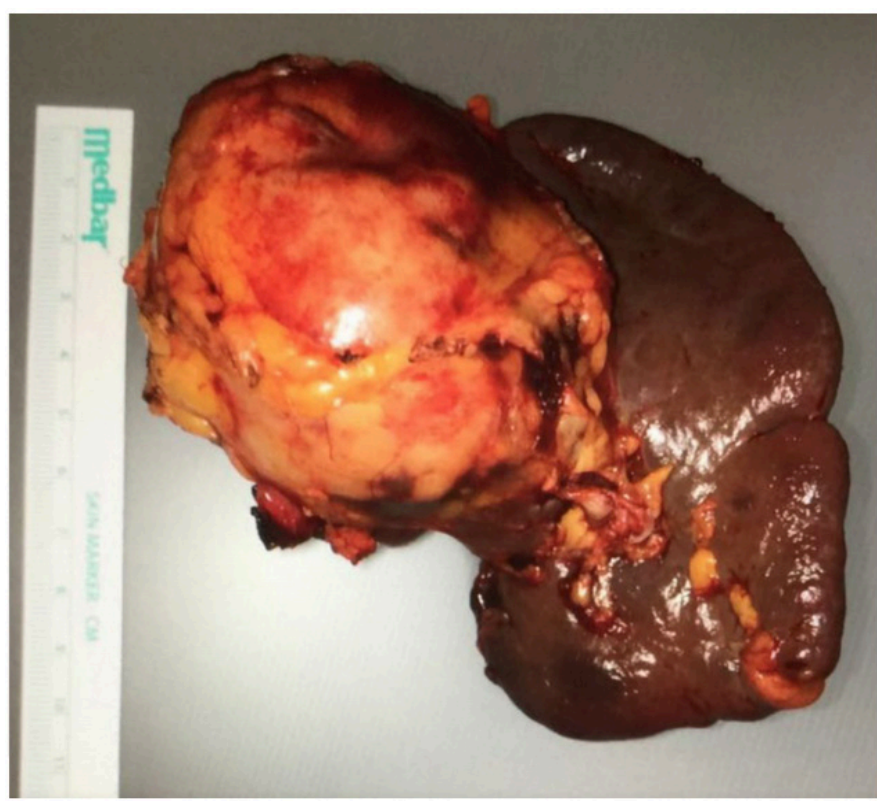

Figure 1. The splenic mass

\section{Discussion}

$\mathrm{HCV}$ is a lymphotropic and hepatotropic virus affecting nearly two hundred million people in the world $(6,7)$. We clearly know that $\mathrm{BNHL}$ is related with $\mathrm{HCV}$ infection. $\mathrm{HCV}$ infection has been reported in nearly $13 \%$ of patients with $\mathrm{BNHL}$ (8). Chronic antigenic stimulation of the immune system by $\mathrm{HCV}$ infection may lead to BNHL. A very similar situation applies to Helicobacter Pylori. MALP lymphoma develops as a result of similar pathology in $H$. Pylori infections (9). T cell-dependent responses are also involved in the pathogenesis of this event. We think that it is very important to decrease the antigenic concentration in the development of malignancy. In addition, we conclude that with the termination of antigenic stimulation, there is a decline in immunity, thus developing lymphoma in an immune organ such as the spleen.

In our case, there was no evidence of malignancy before treatment. However, the development of lymphoma after months of therapy and SVR was interpreted as a lack of immune stimulation. A period of 6-7 months after treatment can be considered as a very short period for the development of lymphoma. However, the fact that there was no mass in the spleen detected by USG before treatment suggests that this condition was related to $\mathrm{HCV}$ treatment.

A similar situation applies to HCC. The probability of HCC relapse following DAA in HCV infection treatment is still unclear. The role of the immune system before and after tumor development is very important. HCV-infected liver cells are constantly alerted by the immune system. If infected cells are destroyed, the efficacy of the immune system in the liver is significantly reduced. In some studies, it has been shown that DAA treatment affects natural killer cells (10). In their study, Chu et al. (11) reported that after DAA treatment, a rapid decrease was seen the level of natural killer group 2, member D protein (NKG2D) which is relased from natural killer cells. The low level NKG2D was correlated with early HCC emergence in DAA-treatment.

Two different study reported increased $\mathrm{HCC}$ after complete response to DAA therapy in patients with $\mathrm{HCV}(3,4)$. At this point, the disorder that occurs in the release of these substances may be accelerating the oncogenic process. Virus-induced inflammation may play an important role in chronic liver injury and in the onset of the tumor development in chronic hepatitis (12). However, at the same time, the immune system is necessary to prevent tumor formation (13). Again, as long as there are cells that are infected with $\mathrm{HCV}$, the immune system is also actively working to destroy these cells. If HCV clearance occurs, the immunosuppressive effect of the system (both for virus-infected cells and tumor cells) is degraded. Immune regression also accelerates tumor development.

Lastly, we think that the risk of cancer in patients receiving DAA suggests that these patients should be monitored closely after therapy is completed.

\section{Ethics}

Informed Consent: Written informed consent was obtained from the patient.

Peer-review: Externally and internally peer-reviewed. 


\section{Authorship Contributions}

Surgical and Medical Practices: O.K., Concept: O.K., Design: E.G., Data Collection or Processing: O.K., E.G., Analysis or Interpretation: T.H., M.K., Literature Search: O.K., E.G., Writing: O.K., E.G., T.H., M.K.

Conflict of interest: The authors declare that they have no conflict of interest.

Financial Disclosure: The authors declared that this study received no financial support.

\section{References}

1. Gupta V, Kumar A, Sharma P, Arora A. Newer direct-acting antivirals for hepatitis C virus infection: Perspectives for India. Indian J Med Res. 2017;146:23-33.

2. Nault JC, Colombo M. Hepatocellular carcinoma and direct acting antiviral treatments: Controversy after the revolution. J Hepatol. 2016;65:663-665.

3. Reig $M$, Mariño $Z$, Perelló $C$, Iñarrairaegui $M$, Ribeiro $A$, Lens S, Díaz A, Vilana R, Darnell A, Varela M, Sangro B, Calleja JL, Forns $X$, Bruix $\mathrm{J}$. Unexpected high rate of early tumor recurrence in patients with HCV-related HCC undergoing interferon-free therapy. J Hepatol. 2016;65:719-726.

4. Conti F, Buonfiglioli F, Scuteri A, Crespi C, Bolondi L, Caraceni P, Foschi FG, Lenzi M, Mazzella G, Verucchi G, Andreone P, Brillanti $\mathrm{S}$. Early occurrence and recurrence of hepatocellular carcinoma in HCV-related cirrhosis treated with direct-acting antivirals. J Hepatol. 2016;65:727-733.

5. ANRS collaborative study group on hepatocellular carcinoma (ANRS CO22 HEPATHER, CO12 CirVir and CO23 CUPILT cohorts). Electronic address: stanislas.pol@aphp.fr. Lack of evidence of an effect of direct-acting antivirals on the recurrence of hepatocellular carcinoma: Data from three ANRS cohorts. J Hepatol. 2016;65:734740 .

6. Chen MH, Hsiao LT, Chiou TJ, Liu JH, Gau JP, Teng HW, Wang WS, Chao TC, Yen CC, Chen PM. High prevalence of occult hepatitis B virus infection in patients with B cell non-Hodgkin's lymphoma. Ann Hematol. 2008;87:475-480.

7. Khaled $H$, Abu-Taleb $F$, Haggag R. Hepatitis $C$ virus and nonHodgkin's lymphomas: A minireview. J Advanc Res. 2017;8:131137.

8. Vannata B, Arcaini L, Zucca E. Hepatitis C virus-associated B-cell non-Hodgkin's lymphomas: what do we know? Ther Adv Hematol. 2016;7:94-107.

9. Kuo SH, Yeh KH, Chen LT, Lin CW, Hsu PN, Hsu C, Wu MS, Tzeng YS, Tsai HJ, Wang HP, Cheng AL. Helicobacter Pylori-related diffuse large B-cell lymphoma of the stomach: a distinct entity with lower aggressiveness and higher chemosensitivity. Blood Cancer J. 2014:4:220.

10. Serti E, Park H, Keane M, O'Keefe AC, Rivera E, Liang TJ, Ghany $M$, Rehermann B. Rapid decrease in hepatitis $C$ viremia by direct acting antivirals improves the natural killer cell response to IFN $\alpha$. Gut. 2017:66:724-735.

11. Chu PS, Nakamoto N, Taniki N, Ojiro K, Amiya T, Makita $Y$ et al. On-treatment decrease of NKG2D correlates to early emergence of clinically evident hepatocellular carcinoma after interferon-free therapy for chronic hepatitis C. PLoS One. 2017 15;12:e0179096.

12. Makarova-Rusher OV, Medina-Echeverz J, Duffy AG, Greten TF. The yin and yang of evasion and immune activation in HCC. J Hepatol. 2015;62:1420-1429.

13. Grivennikov SI, Greten FR, Karin M. Immunity, inflammation, and cancer. Cell. 2010;140:883-899. 